\title{
LEMBAGA PEMASYARAKATAN BERBASIS KOMUNITAS DAN TEKNOLOGI
}

\author{
Emanuel Erian ${ }^{1)}$, Alvin Hadiwono ${ }^{2)}$ \\ 1) Program Studi S1 Arsitektur, Fakultas Teknik, Universitas Tarumanagara, emanueleriann@gmail.com \\ 2) Program Studi S1 Arsitektur, Fakultas Teknik, Universitas Tarumanagara, alvinhadiwono@ymail.com,
}

\begin{abstract}
Abstrak
Sebuah Negara tidak akan terlepas dari isu keamanan dimana tidak akan luput dari kriminalitas. Bentuk kriminalitas yang terjadi di lingkungan masyarakat pada kenyataannya akan mengikuti perilaku masyarakat dari perkembangan generasi. Kenyataan di Indonesia sendiri belum memiliki tipe bangunan Lembaga Pemasyarakatan yang sesuai dengan perilaku narapidana millennial dalam hal pembinaan dan pembentukkan kepribadiannya. Proyek ini mencoba untuk mengembangkan penjara yang berbasis kepada teknologi dan komunitas yang mengikuti perilaku narapidana dan kesejamanan di era millennial. Metode desain yang digunakan dalam perancangan proyek ini yaitu metode tipologi. Desain Lembaga Pemasyarakatan yang dihasilkan adalah berupa bangunan vertikal dengan penerapan banyak ruang komunal dan penggunaan teknologi yang sesuai dengan narapidana millennial saat ini.
\end{abstract}

Kata kunci: komunitas; kriminalitas; Lembaga Pemasyarakatan; millennial; teknologi

\begin{abstract}
A country will not be separated from security issues which can not escape to criminality. The form of crime that occurs in the neighborhood will in fact follow community behavior from the evolution of generations. Reality in Indonesia does not have type of prison building yet that accordance with the of millennial prisoners behavior in terms of their coaching and personality formation. This project tries to develop prisons based on technology and communities that follow prisoner behavior and comtemporaneity in the millennial era. The design method used in designing this project is typology method. The design of Correctional Facility produced is in the form of vertical buildings with the application of many communal spaces and technology used that suitable with current millennial prisoners.
\end{abstract}

Keywords : Correctional Facility; criminality; community; millennial; technology

\section{PENDAHULUAN}

Generasi millennial atau sering juga disebut generation $Y$, generasi ini dapat dikatakan sangat berbeda dengan generasi-generasi sebelumnya sehingga di lingkup manapun mereka berada, mereka tidak mudah untuk dipahami. Menurut data yang didapat dari Fourhooks.com mengatakan bahwa generasi millennial lahir antara tahun 1981-1994. Berbeda dari data Time Magazine, yang tergabung dalam generasi millennial adalah orang-orang yang lahir pada 19802000. Dapat disimpulkan saat ini, generasi millennial pada saat ini berada pada rentang usia produktif, yakni 19-39an tahun. Sebanyak 34\% dari penduduk Indonesia pada saat ini merupakan penduduk usia produktif tersebut dilansir dari Central Bureau of Statistics 2013 dan tentunya populasi ini akan semakin memuncak seiring pertambahan tahun.

Di sisi lain, sebuah Negara tidak akan terlepas dari isu keamanan dimana tidak akan luput dari kriminalitas. Menurut data statistik kriminal 2016, terdapat 357.197 kasus kejahatan di Indonesia dan setiap 1 menit 28 detik terjadi satu tindak kriminal. Dalam buku "New Horizon of Criminology" karya Barnes dan Teeters, mengatakan kriminalitas merupakan fenomena sosial yang tumbuh dan berkembang di masyarakat, yaitu segala perbuatan yang melanggar hukum. Dengan demikian, kejahatan itu tumbuh dan berkembang dalam masyarakat karena kejahatan sebagai salah satu bentuk tingkah laku mengalami perkembangan yang sejajar dengan perkembangan masyarakat itu sendiri.

Bentuk kriminalitas yang terjadi di lingkungan masyarakat pada kenyataannya akan mengikuti perilaku masyarakat dari perkembangan generasi. Teknologi yang terus berkembang 
turut mempengaruhi cara dalam melakukan tindak kriminal. Berdasarkan data dari IndonesiaSecurity Incident Response Team on Internet Infratructure, terdapat 135.672 .984 kejahatan menggunakan perangkat teknologi terutama internet pada tahun 2016. Wakil Kepala Kepolisian RI sendiri menyebutkan Indonesia tercatat sebagai negara kedua tertinggi dalam kejahatan menggunakan dunia maya setelah Jepang.

Tidak dapat dipungkiri bentuk kriminalitas saat ini telah banyak menggunakan teknologi dibanding metode konvensional, disebabkan oleh perilaku pelaku kriminal dan narapidana yang telah berubah di era millennial saat ini. Perkembangan kriminalitas turut diikuti oleh peledakan jumlah narapidana di Indonesia. Menurut data dari Institute for Criminal Policy Research, angka narapidana di Indonesia mengalami peningkatan 5-10\% setiap tahunnya dimana terdapat 256.749 narapidana tahun 2018 dengan jumlah kapasitas rutan dan lapas di Indonesia yang hanya dapat menampung 125.989 orang, sehingga terjadinya overcapacity mencapai $104 \%$. Data dari Direktoral Jenderal Pemasyarakatan menyatakan bahwa 30 dari 33 provinsi di Indonesia mengalami overcapacity dalam menampung narapidana, yang sebagian besar dari mereka adalah sedang dalam usia produktif (millennial). Perubahan generasi telah mengakibatkan pergeseran dan perubahan gaya hidup dalam lingkungan kriminal dan narapidana ketika melakukan kriminalitas. Kenyataan di Indonesia sendiri belum memiliki tipe bangunan penjara yang sesuai dengan perilaku narapidana millennial dalam hal pembinaan dan pembentukkan kepribadiannya. Melihat kenyataan yang terjadi saat ini, maka dibutuhkan pengkonsepsian ulang terhadap tipe bangunan penjara di Indonesia.

Millennial merupakan generasi yang senang membentuk komunitas dalam rangka mendapatkan kesenangan yang positif bagi dirinya serta lingkungan pembangunan di sekitarnya. Aspek kehidupan semakin kompleks, namun hadirnya teknologi informasi telah membawa ketertarikan yang sama dari para millennial hingga mereka membentuk kelompok. Dunia tanpa batas mulai terjalin kapan saja dan dimana saja. Proyek ini mencoba untuk mengembangkan Lembaga Pemasyarakatan yang berbasis kepada teknologi dan komunitas yang mengikuti perilaku narapidana dan kesejamanan di era millennial.

Tujuan pengusulan proyek ini antara lain menciptakan tipe penjara berbasis komunitas dan teknologi yang mengikuti kesejamanan untuk pembentukkan perilaku narapidana khususnya generasi millennial, memberi fasilitas arsitektur baru melalui analisa tipe, perilaku, dan kesejamanan kepada narapidana di Indonesia yang saat ini mengalami over kapasitas di lembaga pemasyarakatan, dan menciptakan program dan sistem yang baru untuk penjara yang berbasis komunitas dan teknologi dalam kaitannya menghukum dan membentuk perilaku narapidana di era millennial.

\section{KAJIAN LITERATUR}

Kamus besar Bahasa Indonesia menjelaskan bahwa Lapas berasal dari kata Lembaga dan Pemasyarakatan. Lembaga adalah organisasi atau badan yang melakukan suatu penyelidikan atau melakukan suatu usaha. Pemasyarakatan adalah nama yang mencakup semua kegiatan yang keseluruhannya di bawah pimpinan Departemen Kehakiman, yang berkaitan dengan pertolongan bantuan atau tuntutan kepada hukuman, bekas hukuman, bekas tahanan, termasuk bekas terdakwa atau yang dalam tindak pidana diajukan ke depan pengadilan dan dinyatakan ikut terlibat untuk kembali ke masyarakat.

Lembaga Pemasyarakatan adalah tempat untuk melakukan pembinaan terhadap narapidana dan anak didik pemasyarakatan di Indonesia. Klasifikasi pada Lembaga Pemasyarakatan berdasarkan kapasitas, tempat kedudukan dan kegiatan kerja.

a) Lembaga Pemasyarakatan Kelas I

Terletak di Ibukota Provinsi dengan kapasitas lebih dari 500 orang.

b) Lembaga Pemasyarakatan Kelas II A Terletak di Kotamadya Kabupaten dengan kapasitas 250-500 orang.

c) Lembaga Pemasyarakatan Kelas II B Terletak di daerah setingkat Kabupaten, kapasitas kurang dari 250 orang. 


\section{Evolusi Penjara}

Penjara sebagai wahana untuk melaksanakan pidana, yaitu suatu pidana pembatasan kebebasan bergerak terhadap seorang terpidana, penjara sudah dikenal orang sejak abad ke-16. Pada masa itu, penjara dilakukan dengan menutup para terpidana di menara, puri, di benteng yang gelap dan kotor, sehingga sangat tidak tidak manusiawi. Ada juga hukuman publik berupa penyiksaan untuk menghasilkan kebenaran kejahatan yang harus dilihat oleh semua orang. Pemberian pidana pada masa itu merupakan perwujudan dari rasa kebencian masyarakat dan sebagai pengungkapan rasa takut masyarakat terhadap para pelanggar hukum.

Hingga pertengahan abad ke-16, dikenal istilah "Bridewell" di Inggris, digunakan untuk penampungan bagi pengemis, gelandangan, dan anak-anak terlantar untuk melatih bekerja. $\mathrm{Di}$ sepanjang abad ke-17, pidana penjara mulai tumbuh sebagai pidana baru yang berbentuk membatasi kebebasan bergerak, merampas kemerdekaan, menghilangkan kemerdekaan yang harus dirasakan sebagai derita selama menjalani pidana penjara. Di Inggris dikenal institusi pidana dengan pembinaan "The House of Correction".

Pidana penjara sebagai pidana yang ditakuti setelah pidana mati mengalami banyak perubahan dari model yang semula paling keras dan kejam tanpa perikemanusiaan sampai model yang paling ringan, longgar sesuai dengan tuntutan zaman, seperti pada abad ke-18 hingga 19. Model pertama pada abad ini adalah sistem Pensylvania, dengan mempraktekkan pembinaan terpidana agar menjadi anggota masyarakat yang produktif. Sistem kedua adalah Auburn Stelsel pada tahun 1784-1855 dengan melaksanakan Theory of Correctional Treatment, namun dalam sistem ini mereka dilarang bercakap-cakap dengan narapidana lainnya saat bekerja (silent system). Sistem ini sukar untuk dipertahankan, karena dilarangnya berbicara bertentangan dengan tabiat manusia. Kemudian pada pertengahan abad ke-19, dikenal sistem Irlandia (Irish System). Sistem ini bersifat progresif, yaitu pada permulaan pidana dijalankan secara keras, tetapi sesudah kelihatan bahwa terpidana berkelakuan baik, maka secara berangsur dijalankannya pidana penjara lebih diringankan dengan "melatih" terpidana menjadi seorang warga masyarakat yang baik. Sistem ini melahirkan "the Rise of the Reformatory" dan telah digunakan di sebagian besar penjara di Indonesia. Selanjutnya, dikenal sistem Elmira dan Borstall di Amerika yang mirip dengan sistem Irlandia dengan diberikannya pembinaan kepada narapidana, namun dengan sistem waktu pidana yang ditentukan berdasarkan perubahan perilaku terpidana itu sendiri. Di abad ke-20, ditemukan sistem Osborne di Amerika. Sistem ini memperkenalkan sistem "self Government" terhadap para napi di dalam penjara dengan diawasi oleh mandor-mandor atau pengawas yang diangkat dari para narapidana sendiri, dalam melakukan pekerjaan baik di dalam penjara maupun luar penjara.

\section{Teknologi untuk Penjara}

Beberapa penjara di dunia saat ini telah menggunakan teknologi-teknologi untuk mendukung berjalannya pengawasan dan pembinaan dalam penjara dan meminimalkan pekerjaan sipir atau pengawas. Berikut beberapa teknologi yang dapat diterapkan dalam penjara di era millennial saat ini dikutip dari buku Kevin Lockyer "Future Prison":

\section{- Biometric Identification \& Tagging Technology}

Gerbang dan pintu keamanan penjara tradisional digantikan oleh sistem kontrol akses terkontrol yang diaktifkan secara biometrik. Pembaca sidik jari mengontrol pintu atau sistem penguncian pintu pagar, tag RFID aktif, dikenakan pada pergelangan tangan atau pergelangan kaki, memungkinkan lokasi tahanan dilacak dan dimonitor. Sensor tekanan menunjukkan dari jarak jauh jika tag dilepas. Sistem biometrik pada dasarnya adalah sistem pengenalan/identifikasi pribadi dengan menentukan keaslian dari suatu karakteristik fisiologis, ataupun perilaku tertentu yang dimiliki oleh si pengguna.

- Prisoner "Self Service"

Teknologi ini memungkinkan narapidana untuk melaksanakan kegiatan administrasi rutin mereka yang non-sensitif secara mandiri. Hal ini memberikan mereka kesempatan untuk 
mengatur tugas mereka dan menanamkan rasa tanggung jawab pribadi. Saat ini, teknologi ini memungkinkan narapidana untuk melakukan self-help untuk tugas-tugas sebagai berikut:

- Melakukan permintaan administrasi seperti penggantian tag pergelangan tangan, mengecek staf medis, dll.

- Memerika dan menebus hak.

- Mencetak surat.

- Memeriksa status permintaan mereka.

- Mendapatkan informasi-narapidana lainnya.

- Memeriksa ketersediaan program studi baru dan e-learning.

- Smart Cell with Smart CCTV

Beberapa penjara di dunia juga telah menerapkan ruang sel berbasis teknologi untuk mendukung pengawasan dan pembentukkan perilaku narapidana. Smart cell merupakan sistem rumah narapidana yang sudah terhubung dengan sensor RFID (Biometrik) serta kamera pintar (smart CCTV) untuk pengawasan perilaku narapidana. Sistem CCTV yang digunakan juga dilengkapi dengan sensor yang sanggup mengidentifikasi kelakuan tak normal, perkelahian, hingga percobaan bunuh diri narapidana.

\section{- E-Learning}

Program pembinaan di penjara juga dapat menggunakan sistem e-learning yang mengikuti perkembangan jaman saat ini. Sistem ini dapat diterapkan seperti di perpustakaan dan ruang pembinaan. Penggunaan teknologi elektronik dan informasi juga bertujuan untuk membina narapidana dalam pengenalan dan penggunaan teknologi informasi yang tepat, sehingga dapat merehabilitasi perbuatan kriminal melalui perangkat ini. Namun, dengan diberikannya teknologi informasi dalam pembinaan narapidana, dibutuhkan juga pengawasan dalam cyber security sehingga dapat mengontrol perilaku narapidana dalam penggunaan e-learning.

\section{Perilaku Narapidana Millennial}

Perkembangan generasi saat ini pun turut merubah perilaku narapidana dalam lingkungan penjara. Dikutip dari buku Yoris Sebastian "Generasi Langgas Millennials Indonesia" dan Kevin Lockyer "Future Prison", berikut merupakan perilaku umum narapidana millennial :

- Better for Prisoners and Family

Narapidana millennial menilai bahwa old values seperti hormat pada orang tua menjadi sesuatu yang sangat berharga. Apalagi sebagian besar orang tua pada generasi mereka tidak sekeras orang tua pada generasi sebelumnya. Ditambah era media sosial yang dengan mudah menampilkan kedekatan millennial dan keluarganya, sehingga mendorong orang lain yang melihatnya untuk lebih dekat dengan keluarga mereka.

\section{- Community, Collective, \& Connected}

Millennial merupakan generasi yang senang membentuk komunitas dalam rangka mendapatkan kesenangan yang positif bagi dirinya serta lingkungan pembangunan di sekitarnya. Aspek kehidupan semakin kompleks, namun hadirnya teknologi informasi telah membawa ketertarikan yang sama dari para millennial hingga mereka membentuk kelompok. Dunia tanpa batas mulai terjalin kapan saja dan dimana saja. Internet membuka banyak koneksi baru dengan dunia luar.

- Eliminate the Need for Staff

Penjara dengan sistem Teknologi Informasi memungkinkan narapidana untuk melakukan aktivitasnya sendiri tanpa banyak tergantung pada sipir atau petugas. Pada kenyataannya, millennial merupakan generasi yang mandiri dan generasi yang paling berpendidikan, sehingga dapat dengan tanggap melakukan kegiatan sehari-hari dan menanamkan rasa tanggung jawab dalam diri narapidana.

\section{- Digital Coaching}

Tidak dapat dipungkiri jika narapidana millennial pun lahir dalam keadaan teknologi informasi yang telah berkembang, sehingga memungkinkan mereka untuk lincah dan tidak asing lagi 
dalam menggunakan teknologi. Bahkan, untuk saat ini teknologi seakan menjadi kebutuhan yang tak terpisahkan dari generasi millennial dalam kehidupan sehari-harinya. Hal ini dapat diterapkan dalam lingkungan penjara dengan memberi fasilitas dan pembelajaran teknologi informasi bagi narapidana di era millennial ini.

\section{METODE}

Metode desain yang digunakan dalam perancangan proyek ini yaitu metode tipologi yang dikemukakan oleh Louis Durand pada pertengahan abad ke-19, yang melihat arsitektur sebagat suatu seni menata elemen-elemen yang sudah ada (kolom, entrance, tangga, dsb) dalam komposisi orthogonal untuk mendapat solusi yang sederhana dan ekonomis. Teori ini kembali dihidupkan oleh Aldo Rossi pada tahun 1960 sebagai metode desain, yang diakuinya membuat lingkungan menjadi lebih terpahami dan mewujudkan memori kolektif sebuah komunitas. Tipologi berasal dari bahasa yunani, yaitu typos, yang bermakna impresi, jenis, dan logos, yang berarti ilmu, sehingga tipologi dapat diartikan sebagai ilmu yang berkenaan dengan tipe. Dalam perancangan ini, akan digunakan metode kualitatif untuk menginvestigasi esensi dan tipologi dari penjara melalui studi evolusi dan presedennya.

\section{DISKUSI DAN HASIL}

\section{Analisa Kawasan Jakarta}

Menurut data dari Institute for Criminal Policy Research, angka narapidana di Indonesia mengalami peningkatan $5-10 \%$ setiap tahunnya dimana terdapat 256.749 narapidana tahun 2018 dengan jumlah kapasitas rutan dan lapas di Indonesia yang hanya dapat menampung 125.989 orang, sehingga terjadinya overcapacity mencapai $104 \%$. Data dari Direktoral Jenderal Pemasyarakatan menyatakan bahwa 30 dari 33 provinsi di Indonesia mengalami overcapacity dalam menampung narapidana, yang sebagian besar dari mereka adalah sedang dalam usia produktif (millennial). Jakarta berada pada posisi ketiga teratas dalam masalah overcapacity rutan dan lapas di Indonesia.

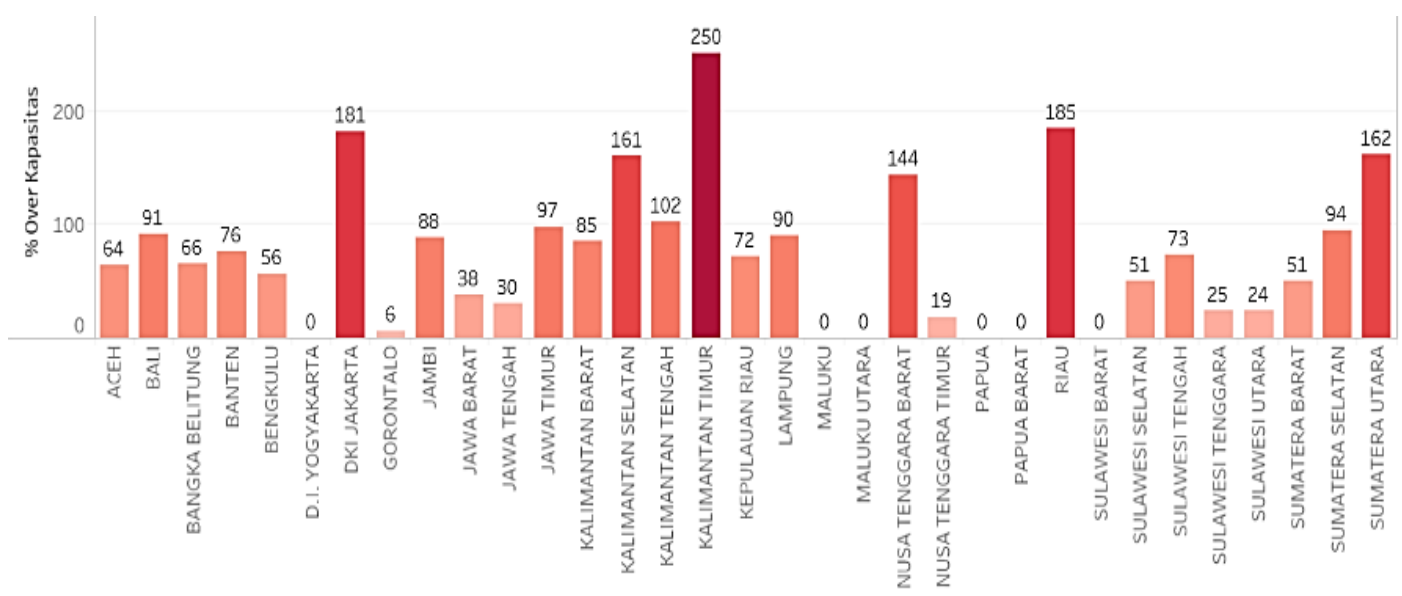

Gambar 1. Diagram Over kapasitas Penjara menurut Provinsi Sumber: www.balitbangham.go.id

Kota Jakarta sendiri telah mempunyai 3 Rumah Tahanan dan 9 Lembaga Pemasyarakatan yang tersebar di kotanya dengan masing-masing bagian kotanya terdapat fasilitas Pengadilan dan dan kantor Kejaksaan. Berikut merupakan peta persebaran Rutan dan Lapas di Jakarta berserta fasilitas Pengadilan dan Kejaksaan. 


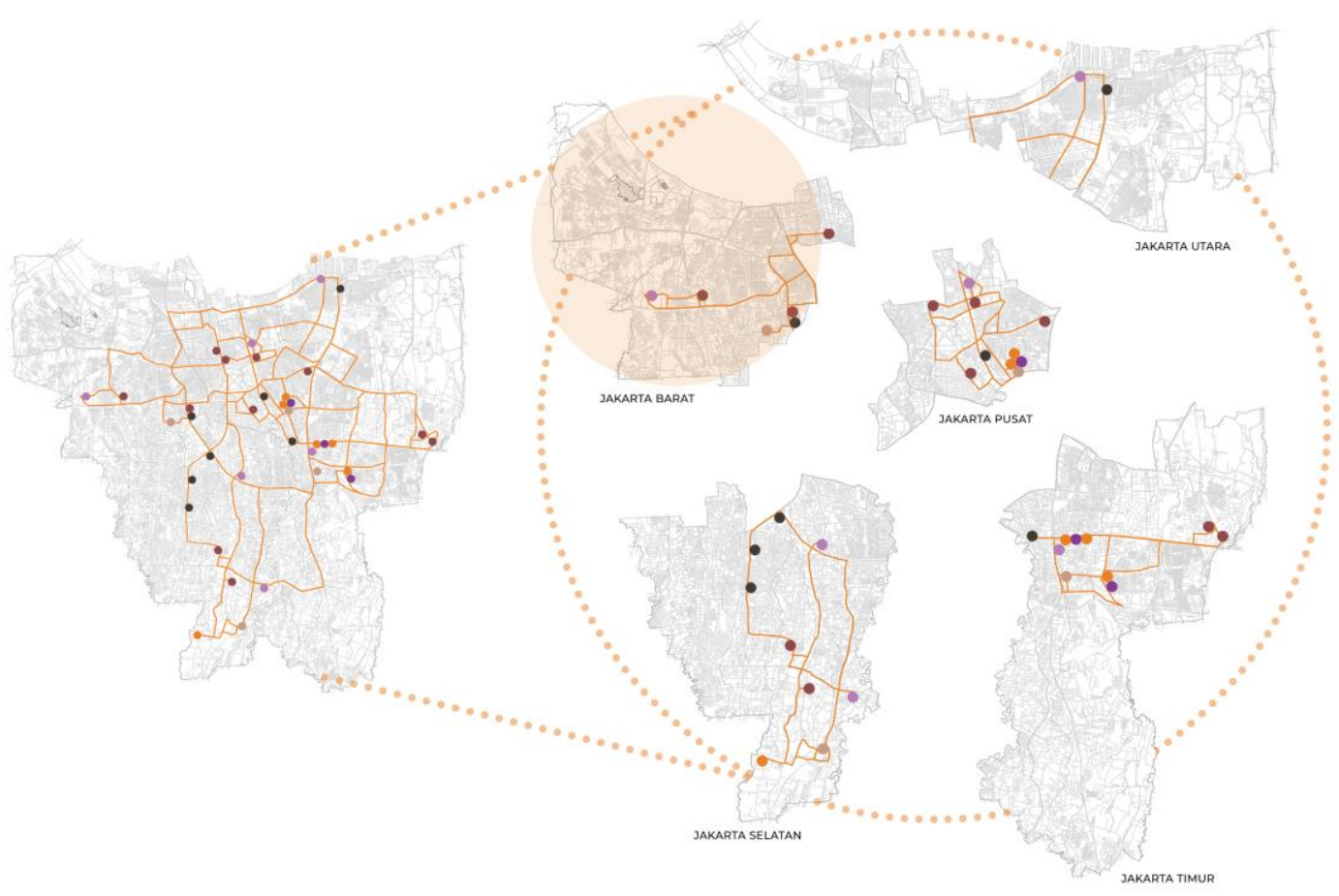

Gambar 2. Analisa Persebaran Lapas dan fasilitas pendukungnya di Jakarta Sumber: Penulis, 2019

Dari analisa diatas, dapat disimpulkan bahwa Jakarta Timur, Pusat, dan Selatan adalah daerah yang telah memiliki Lembaga Pemasyarakatan beserta fasilitas pendukungnya, berbeda dengan Jakarta Barat dan Utara yang belum memiliki Lembaga Pemasyarakatan, namun wilayah Jakarta Barat telah memiliki fasilitas pendukung Lapas yang memadai sehingga berpotensi untuk pengembangan Lapas yang baru.

\section{Analisa Jakarta Barat}

Zona pemerintahan yang ada di Jakarta Barat tersebar merata dan rata-rata merupakan tanah yang telah terbangun sehingga perlu adanya penambahan zona pemerintah untuk fasilitas Lapas yang baru. Terdapat banyak jalan arteri di Jakarta Barat yang sudah terhubung dengan baik dan mendukung aksebilitas untuk Lapas seperti jalan Letjen S. Parman, Kebon Jeruk, Lingkar Luar W1, hingga jalur Pantura. Jalur transportasi di Jakarta Barat yang sudah memadai sebagian besar terletak di sepanjang jalur arteri seperti di sepanjang jalan Letjen S.Parman dan Daan Mogot. Terdapat pula beberapa titik rawan kriminalitas di Jakarta Barat seperti Cengkareng, Daan Mogot, Mangga Besar, Tomang, Slipi, dan beberapa daerah perempatan yang merupakan kawasan-kawasan yang berpotensi untuk di bangun Lapas

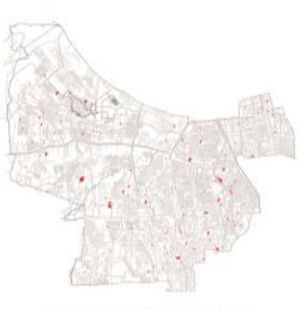

FASILITAS PEMERINTAHAN

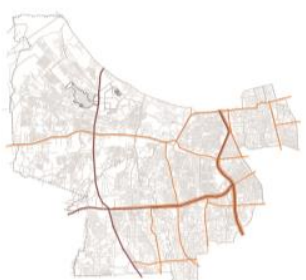

SIRKULASI JALAN - jalur arteri

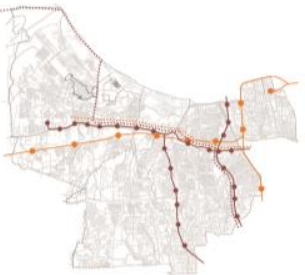

JALUR TRANSPORTASI UMUM

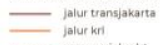

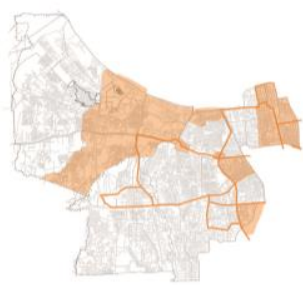

DAERAH RAWAN KRIMINALITAS

Gambar 3 : Analisa Jakarta Barat

Sumber: Penulis, 2019 


\section{Analisa Kawasan Palmerah}

Daerah palmerah merupakan daerah yang cukup padat dengan pola bangunan yang kebanyakan terbangun secara organik. Bangunan-bangunan besar dan tinggi kebanyakan terletak di sepanjang jalan tol Letjen S.Parman. Area Palmerah dilintasi oleh jalur arteri Letjen S.Parman dan terdapat beberapa cabang menuju jalan kolektor. Strategi penetapan tapak perancangan adalah memilih site di jalan arteri dan dekat dengan fasilitas penunjang lapas yang lainnya. Terdapat 3 halte transjakarta yang sudah terbangun dan beroperasi di sepanjang jalan tol Letjen S.Parman sehingga memudahkan aksebilitas menuju Lapas.

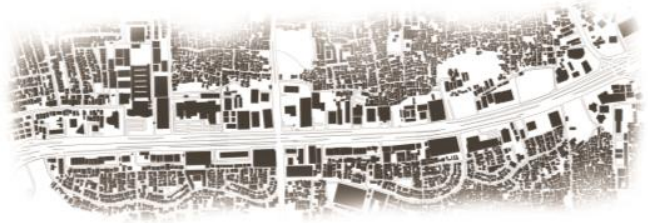

SOLID VOID \& URBAN FABRIC

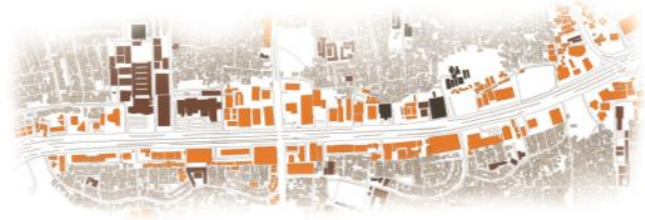

TATA GUNA LAHAN

zona perumahan
zona perdagangan 8 jase

zona sosial 8 budaya

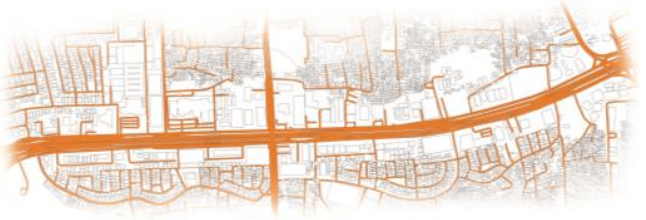

AKSEBILITAS \& SIRKULASI JALAN

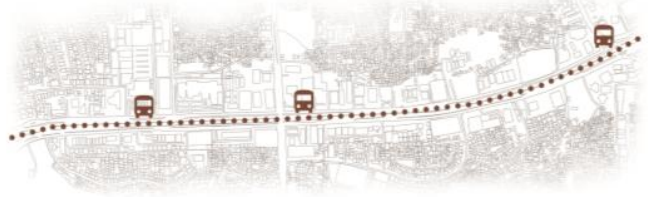

PRASARANA TRANSPORTASI UMUM

Gambar 4. Analisa daerah jalan tol Palmerah Sumber: Penulis, 2019

Tapak terletak di jalan Letjen S.Parman yang telah terdapat banyak bangunan tinggi di sepanjang jalur ini. Strategi peletakkan Lapas adalah mengambil lokasi tanah yang dekat dengan fasilitas pendukung Lapas di Jakarta Barat, yaitu tepat di samping polres metro Jakbar, 200 m dari Pengadilan Jakarta Barat dan sekitar 1,5 km dari Balai Pemasyarakatan.

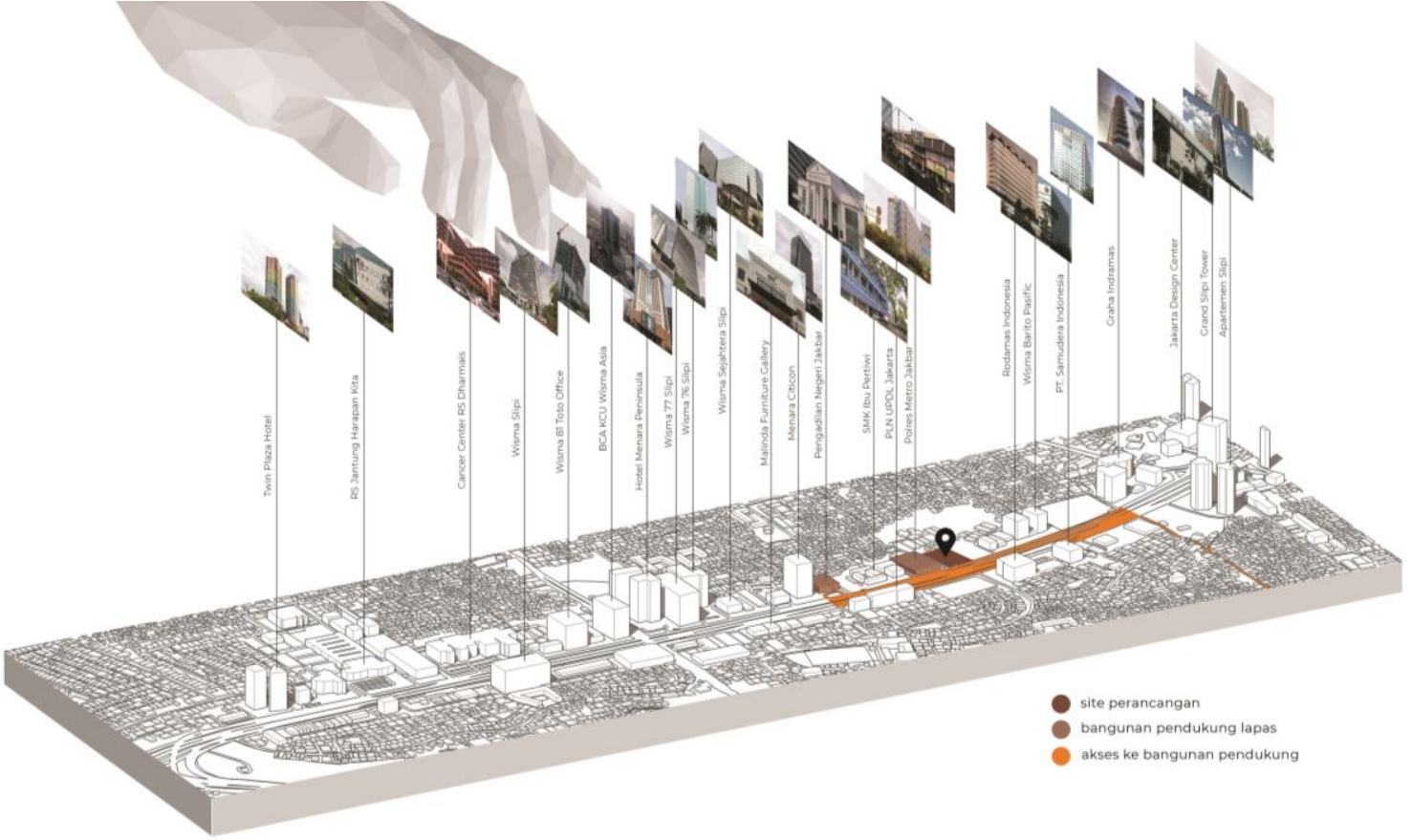

Gambar 5. Analisa Ketinggian Bangunan Sumber: Penulis, 2019 


\section{Strategi Desain dan Perencanaan}
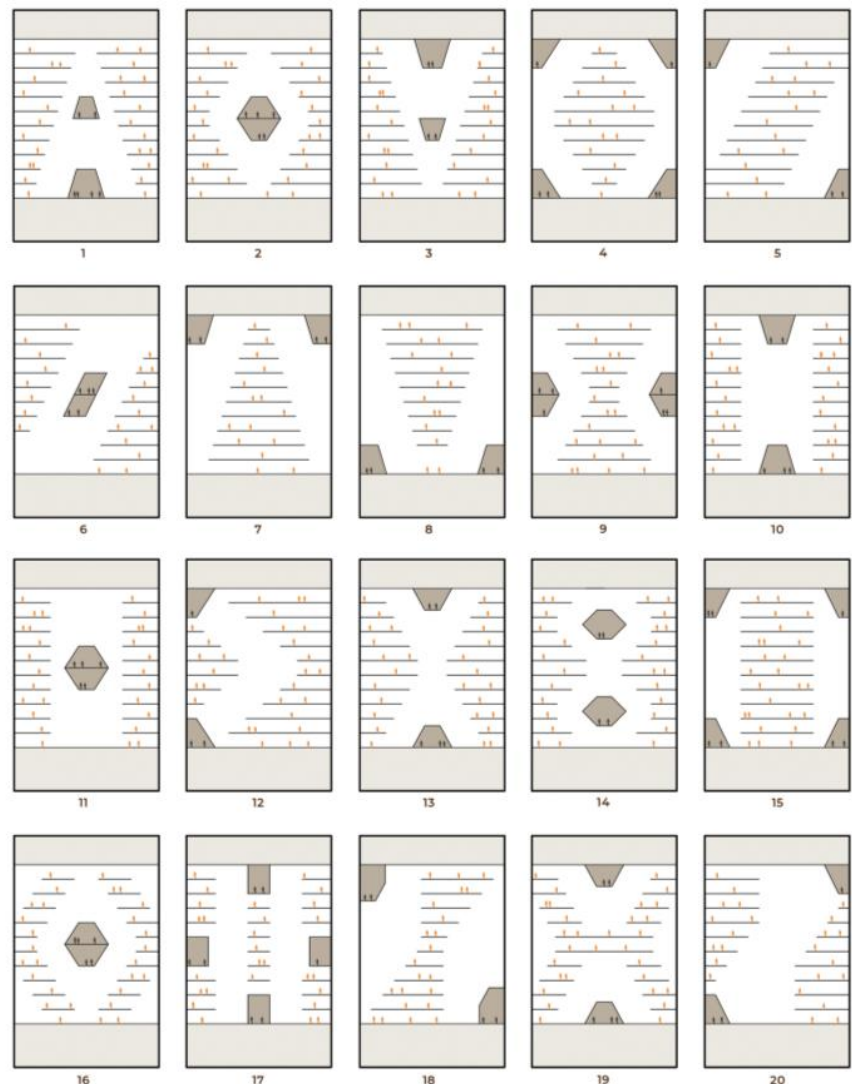

Gambar 6 : Studi Tipe Solid Void Ruang Penjara

Sumber: Penulis, 2019

Gambar di atas merupakan studi ruang bangunan Lapas secara vertikal yang nantinya akan menghasilkan solid dan void yang berbeda-beda dan menghasilkan banyak kemungkinan (possibilities) yang paling efektif untuk diterapkan di bangunan Lapas vertikal yang terletak di tengah kota yang padat. Terdapat beberapa aspek dalam menentukkan tipe ruang yang lebih efektif untuk Lapas, seperti peletakkan zona, jarak pandang langsung untuk keamanan, ruangruang yang terbentuk, bentuk void dan kelebihannya, dan sebagainya.

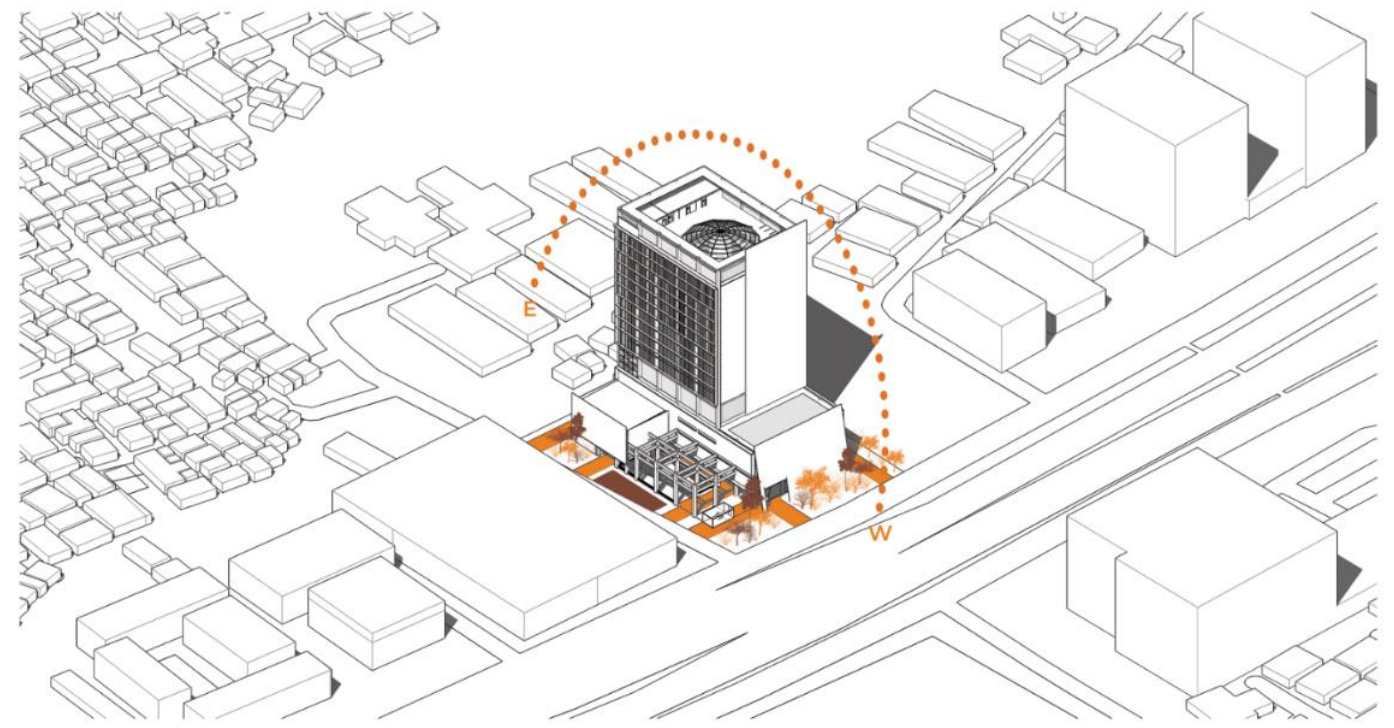

Gambar 7. Design Scheme bangunan

Sumber: Penulis, 2019 
Tapak existing berada di jalan Letjen S.Parman tepat di sebelah Polres Metro Jakarta Barat dan berdekatan dengan beberapa fasilitas pendukung Lapas lainnya. Studi tipe yang telah dilakukan sebelumnya kemudian diterjemahkan ke dalam bentuk 3 dimensi. Bangunan di ekstrude secara vertikal untuk menanggapi area site yang sempit dan terletak di tengah kota dengan konteks bangunan sekitar yang vertikal. Penambahan podium di bagian bawah bertujuan untuk memaksimalkan KLB bangunan dan menambahkan ruang-ruang baru dalam bangunan. Fasad menggunakan material yang massive mengikuti tipologi penjara pada umumnya seperti beton, jeruji besi, dan bukaan yang kecil. Orientasi kamar sel diletakkan di utara dan selatan dengan pemberian sedikit bukaan, sedangkan bagian timur dan barat diletakkan core dan shear wall untuk memimalisir panas matahari. Terdapat juga skylight di bagian atap tower untuk pencahayaan alami sepanjang hari.

\section{KESIMPULAN DAN SARAN}

Desain Lembaga Pemasyarakatan yang dihasilkan adalah berupa bangunan vertikal dengan penerapan banyak ruang komunal dan penggunaan teknologi yang sesuai dengan narapidana millennial saat ini. Ruang-ruang komunal diterapkan di tipe sel penjara dan ruang kumpul di setiap lantai penjara, dan di ruang-ruang edukasi. Sedangkan untuk teknologi penjara sendiri juga menerapkan sistem keamanan biometric identification yang menggunakan sistem kontrol secara biologis. Terdapat pula penerapan Smart Cell untuk seluruh sel dengan penggunaan Smart CCTV yang dapat mendeteksi kelakuan tak normal, perkelahian, hingga percobaan bunuh diri narapidana. Selain itu, terdapat pula "prisoner self service" dan e-learning yang bertujuan membina narapidana dalam pengenalan dan penggunaan teknologi informasi yang tepat, sehingga dapat merehabilitasi perbuatan kriminal melalui perangkat ini.
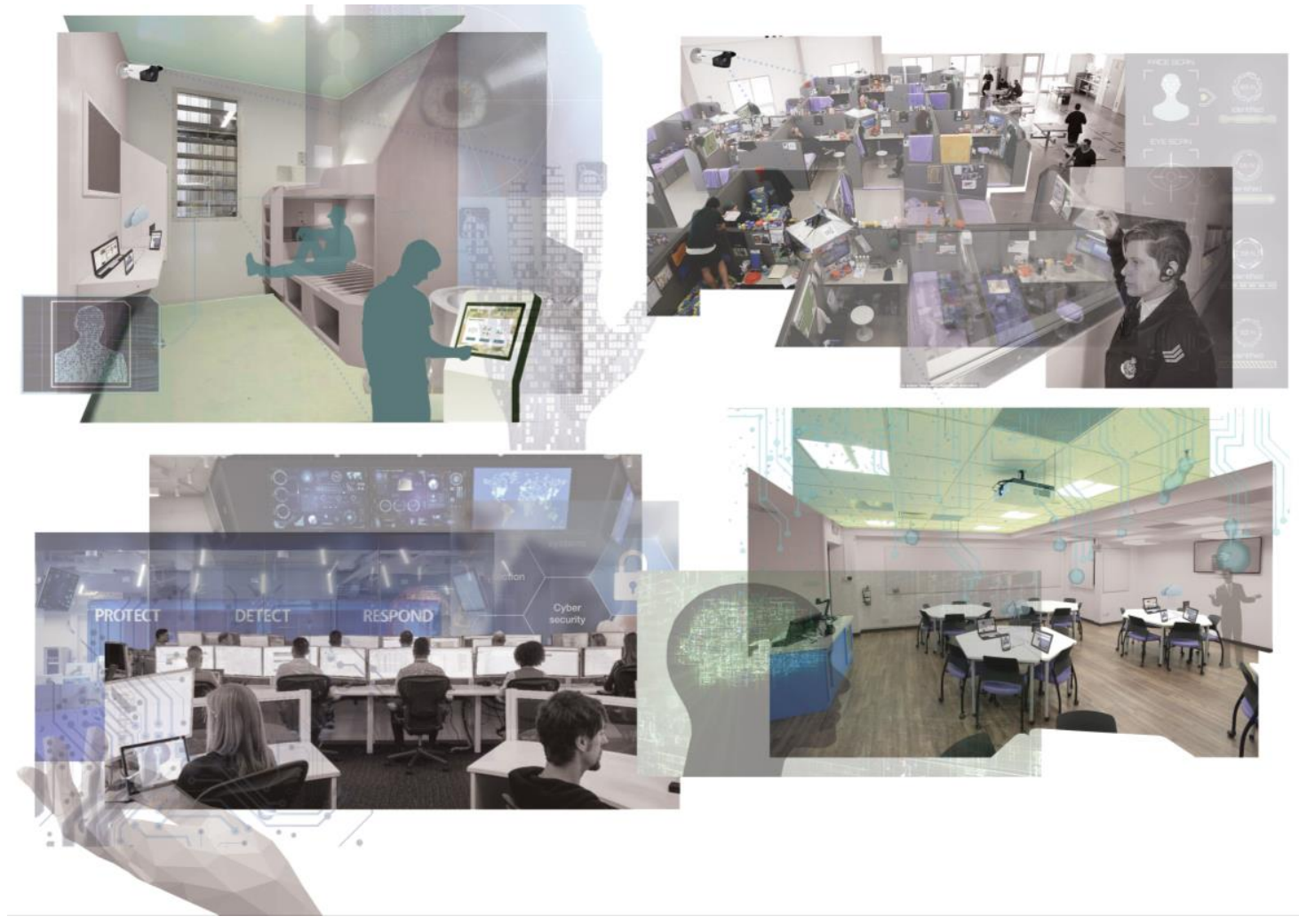

Gambar 8. Gambaran Konsep Ruang Sumber: Penulis, 2019 
Zona lantai dasar sebagian besar digunakan untuk ruang publik. Podium di fungsikan untuk area administrasi Lapas dan poliklinik. Terdapat juga ruang kunjungan, area edukasi dan lapangan olahraga. Lantai 5 digunakan untuk zona bertani/berkebun dengan dinding yang menggunakan chainlink fence sehingga memungkinkan cahaya dan udara alami masuk. Area tower digunakan sepenuhnya untuk ruang penjara dengan terdapat 4 tipe ruang sel, ruang-ruang komunal, dan area servis penjara.

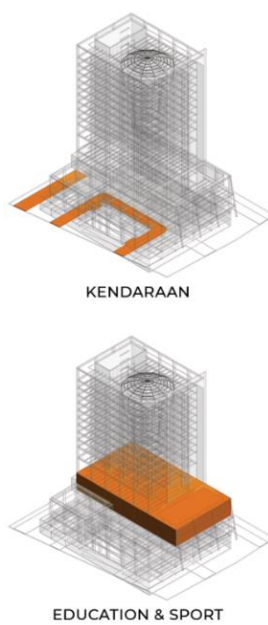

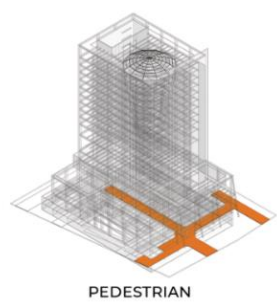

PEDESTRIAN

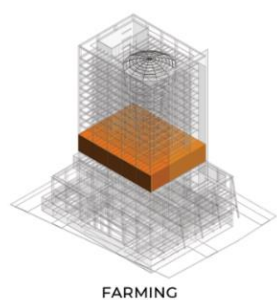

FARMING

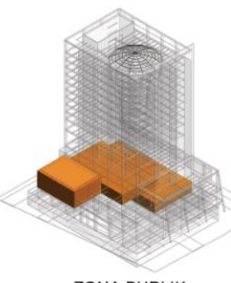

ZONA PUBLIK

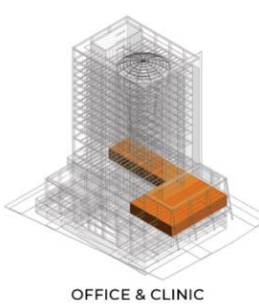

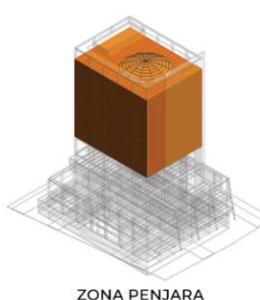

ZONA PENJARA

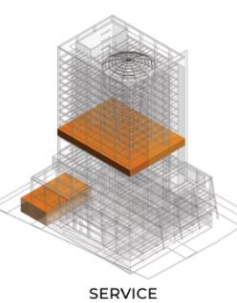

Gambar 9 : Diagram Zoning Bangunan Sumber: Penulis, 2019

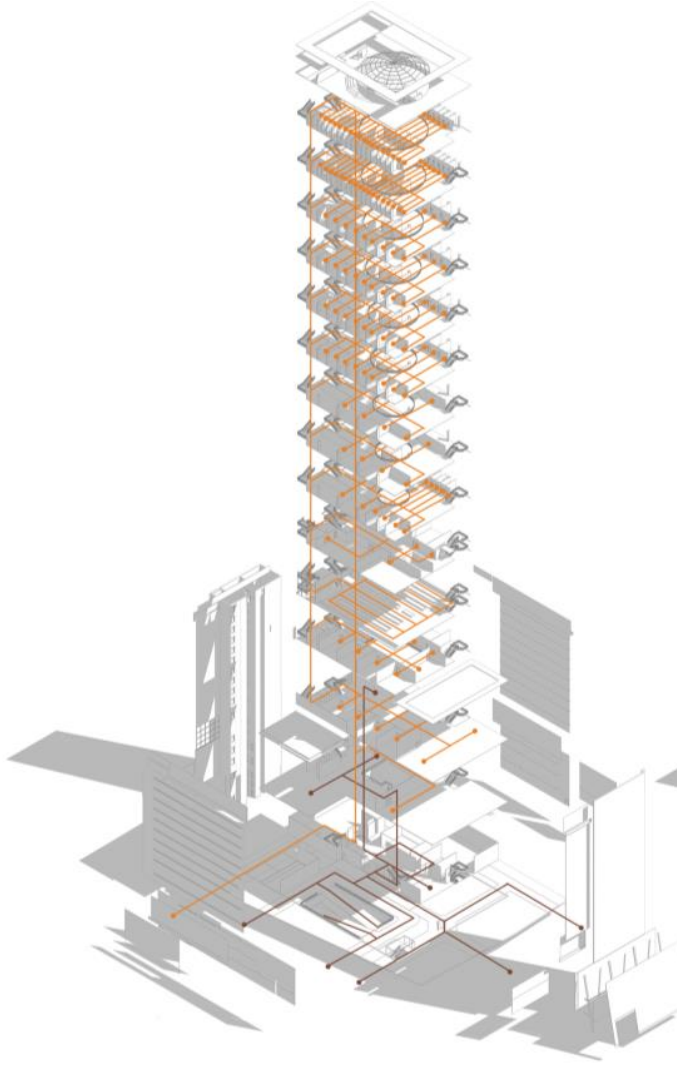

KETERANGAN:
narapidanna
Pengungung

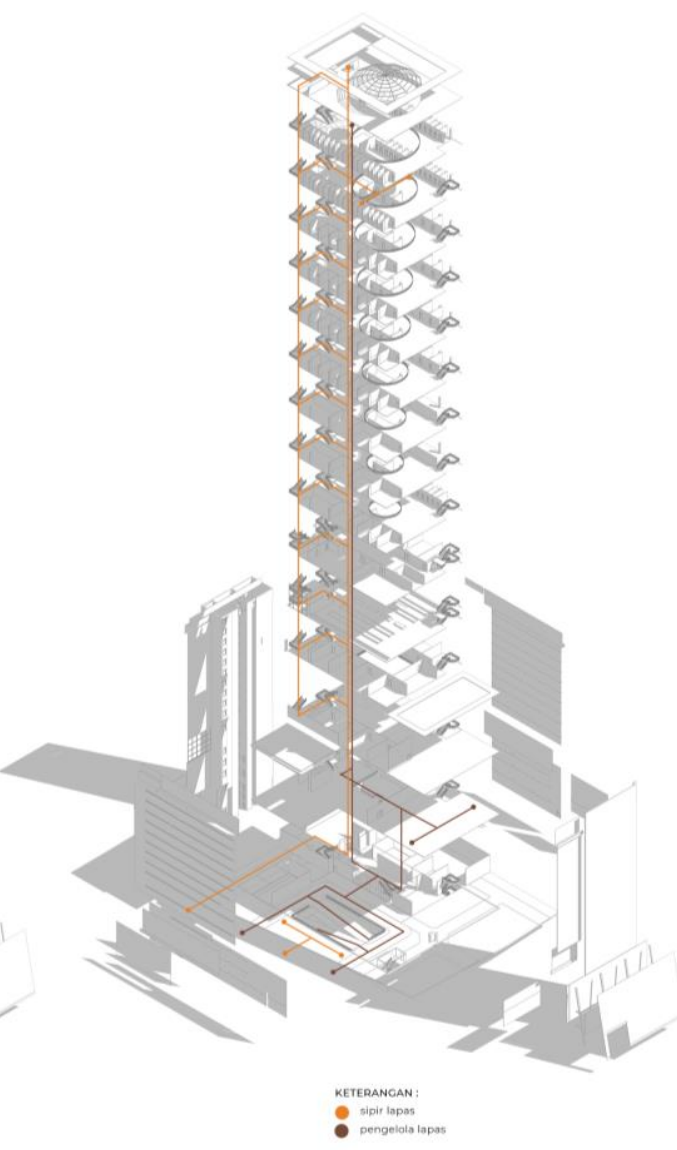

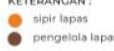

Gambar 10. Diagram Axonometri Sirkulasi Pengguna Sumber: Penulis, 2019 
Sistem struktur menggunakan prinsip grid pada umumnya dengan terdapat beberapa kolom miring di tower yang menyesuaikan dengan bentukkan void di tower. Balok induk berukuran $40 \times 70 \mathrm{~cm}$ dan balok anak berukuran 20x40 cm dengan diletakkan di setiap luas 16-25 m² lantai. Terdapat juga penggunaan beberapa struktur bentang lebar seperti di multifunction room, struktur dome, dan di sport hall.

Area MEP diletakkan sebagian besar di basement, lantai dasar, dan lantai atap. Sistem plumbing yang digunakan di menggunakan sistem down fit, yaitu sistem yang menyalurkan air bersih dengan cara memompa kebutuhan air bersih ke atap bangunan (reservoir atas) yang selanjutnya dapat turun langsung melalui tarikan gravitasi ketika air dinyalakan. Listrik pada bangunan bersumber dari pln yang didistribusikan melalui panel-panel ke bangunan. Sistem udara di bangunan tower dan podium menggunakan sistem AC VRV, dan daerah basement menggunakan udara alami dengan dibantu fan. Mesin VRV diletakkan di 2 tempat, yaitu berada di atas tower digunakan untuk daerah tower, dan di daerah halaman luar ground floor untuk daerah podium dan beberapa ruangan di basement.

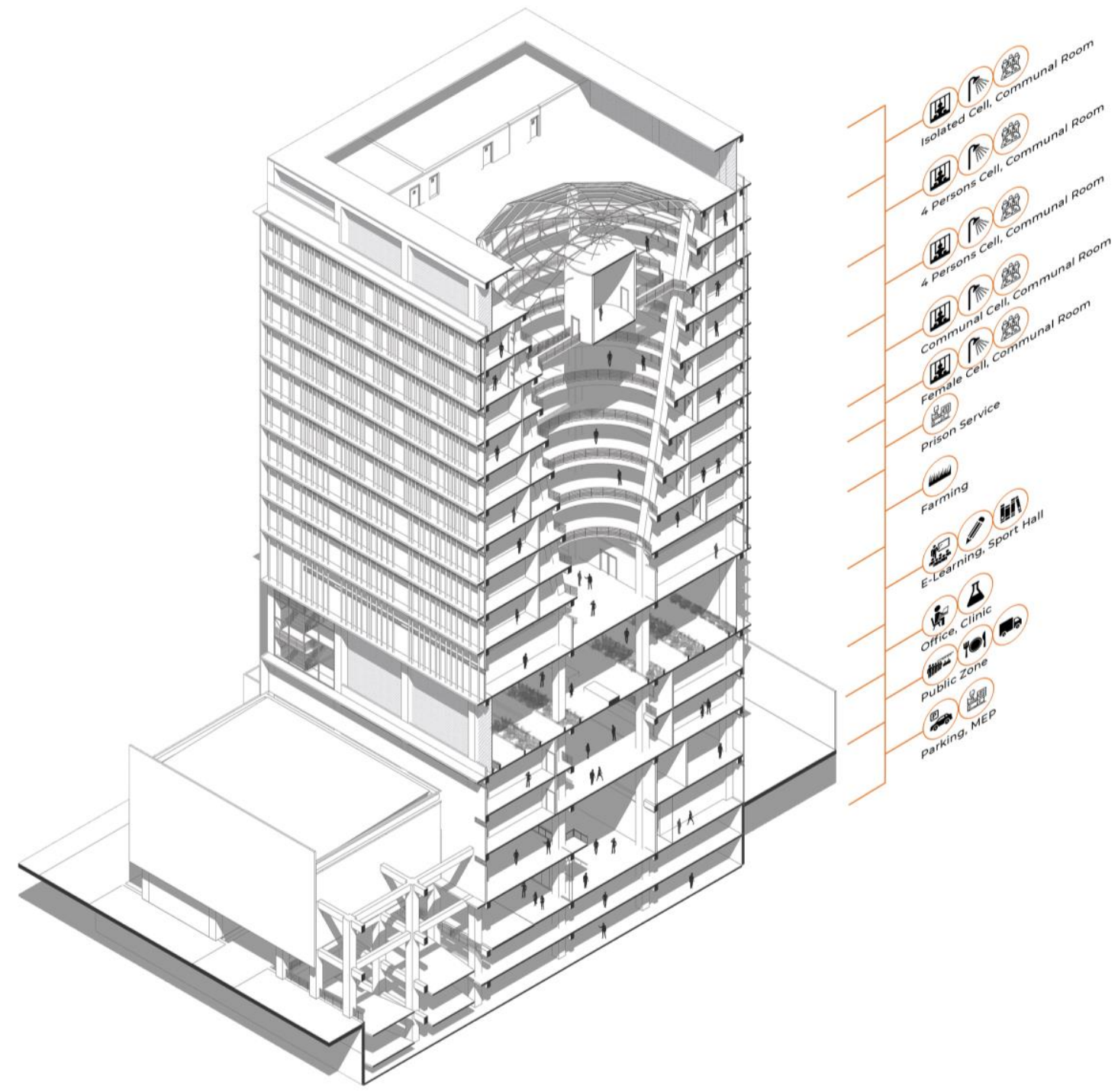

Gambar 11 : Potongan Axonometri Bangunan Sumber: Penulis, 2019 


\section{Saran}

Kenyataan yang terjadi pada Lapas di Indonsia adalah tidak tercukupinya kapasitas untuk menampung narapidana yang terus bertumbuh, sementara itu ruang dan pembinaan yang didapat dari pemasyarakatan belum membentuk narapidana yang mengikuti kesejamanan (millennial), terkait dengan perilaku mereka ketika melakukan kriminalitas. Sehingga, dibutuhkan pengkonsepsian ulang dari desain tipe lembaga pemasyarakatan di Indonesia yang mengikuti perkembangan generasi.

\section{REFERENSI}

Bieleferd, B. (2013). Basic Architectural Design. Basel : Birkhauser.

Farhan, R., F. (2017). Dinamika Sosial dan Perkembangan Kejahatan di Indonesia.

Gennaro, G. D. (1975). Prison Architecture. The Architectural Press Ltd, London.

Hisyam, C. J. (2018). Perilaku Menyimpang, Tinjauan Sosiologis. Bumi Aksara.

Kristyanto. (2011). Pembinaan Perilaku Narapidana Di Lembaga Pemasyarakatan Kelas IIA

Pekalongan.

Lockyer, K. (2013). Future Prison, Policy Exchange.

MarcComm, MIX (2018). Millennials. Danas, Jakarta : Fantasious x Loveable.

Sebastian, Y. (2016). Generasi Langgas, Millennials Indonesia. Gagas Media.

Teeters, B. (1959). New Horizons in Criminology, Prentice-Hall.

Vessella, L. (2017). Prison, Architecture and Social Growth: Prison as an Active Component of the

Contemporary City.

Widodo. (2014). Urgensi Pembentukkan Model Pembinaan dan Pembimbingan Berbasis

Kompetensi Bagi Narapidana Pelaku CyberCrime.

http://www.balitbangham.go.id/detailpost/data-lapas-di-indonesia-agustus-2017

https://www.cnnindonesia.com/nasional/20180717140856-12-314780/polri-indonesiatertinggi-kedua-kejahatan-siber-di-dunia

http://smslap.ditjenpas.go.id/public/grl/current/monthly/sort:jml_ndl/asc/page/0

https://govinsider.asia/innovation/how-singapore-is-using-tech-to-rehabilitate-prisoners/

http://www.prisonstudies.org/country/indonesia

https://www.researchgate.net/publication/320557561_Pengertian_dan_Sejarah_Singkat_Pemasyarakatan

https://www.suara.com/tekno/2019/02/15/224325/hong-kong-siap-kenalkan-teknologipenjara-cerdas

https://www.validnews.id/Silang-Sengkarut-Kejahatan-Siber-di-Indonesia-dDv 